\title{
PELA GANDONG SEBAGAI SARANA PENYELESAIAN KONFLIK
}

\author{
Julia Malisngorar \\ Fakultas Hukum Universitas Wijaya Kusuma Surabaya \\ e-mail: jmalisngorar@gmail.com \\ Besse Sugiswati \\ Fakultas Hukum Universitas Wijaya Kusuma Surabaya \\ e-mail:kietaw53@yahoo.com
}

\begin{abstract}
ABSTRAK
Penelitian yang berjudul Pela Gandong Sebagai Sarana Penyelesaian Konflik Di Maluku, bertujuan Pertama, untuk mengetahui dan menganalisa peran Pela Gandong dalam tradisi masyarakat Maluku. Kedua, untuk mengetahui dan menganalisa Pela Gandong dilihat dalam konteks Undang-Undang Nomor 7 Tahun 2012. Berdasarkan hasil penelitian dapat disimpulkan bahwa Pertama, konflik merupakan perseteruan dan atau benturan fisik dengan kekerasan antara dua kelompok masyarakat atau lebih, yang berlangsung dalam waktu tertentu dan berdampak luas, yang mengakibatkan ketidakamanan dan disintegrasi sosial sehingga mengganggu stabilitas nasional dan menghambat pembangunan nasional. Ketiga, Pela berarti suatu ikatan, sedangkan Gandong berarti bersaudara, jadi Pela Gandong adalah suatu ikatan persatuan dan saling mengangkat saudara. Ketiga, penyelesaian konflik yang terjadi di Maluku menurut Undang-Undang Nomor 7 Tahun 2012 memberikan porsi bagi pranata adat untuk menyelesaikan konflik tersebut, hasil kesepakatan penyelesaian konflik melalui pranata adat memiliki kekuatan yang mengikat bagi kelompok masyarakat yang terlibat dalam konflik.
\end{abstract}

Kata Kunci: konflik sosial, pela gandong, penyelesaian konflik sosial.

\begin{abstract}
The research, entitled "Pela Gandong as a Conflict Resolution Tool in Maluku" aims First to know and analyze the role of Pela Gandong in Maluku society tradition. Secondly, to know and analyze Pela Gandong in the context of Law Number 7 Year 2012. Based on the research result, it can be concluded that First, conflict is a feud and/or physical clash with violence between two or more community groups that take place within a certain time and have a wide impact, resulting in insecurity and social disintegration that disrupts national stability and impedes national development. Secondly, Pela means a bond, while Gandong means siblings, so Pela Gandong is a bond of unity and raising one another. Third, the resolution of the conflict in Maluku according to Law No. 7 of 2012 provides a portion for customary institutions to resolve the conflict, the result of the settlement of the conflict through customary institutions has a binding force for the community groups involved in the conflict.
\end{abstract}

Keywords: social conflict, pela gandong, social conflict resolution.

\section{PENDAHULUAN}

Negara Indonesia merupakan negara hukum yang bersifat demokratis berdasarkan Pancasila dan Undang-Undang Dasar 1945. Sumber hukum dibagi menjadi dua baik secara tertulis maupun hukum tidak tertulis, keduanya memiliki peranan yang sangat besar bagi terciptanya ketertiban dan keamanan dalam masyarakat sekaligus merupakan landasan bagi pelaksanaan hukum di Indonesia.
Hukum tidak hanya dilihat sebatas rumusan yuridis saja, tetapi lebih dari itu harus dilihat pula berbagai norma hukum yang hidup dan berlaku dalam masyarakat yang keseluruhannya tercakup dalam hukum adat. Setelah amandemen konstitusi, hukum adat diakui sebagaimana dinyatakan dalam Undang-Undang Dasar 1945 Pasal 18 ayat (2) yang menyatakan Negara mengakui dan menghormati 
kesatuan-kesatuan masyarakat hukum adat beserta hak-hak tradisionalnya sepanjang masih hidup dan sesuai dengan perkembangan masyarakat dan prinsip negara Kesatuan Republik Indonesia, yang diatur dalam undang-undang ini. Memahami rumusan Pasal 18B Undang-Undang Dasar 1945 tersebut maka konstitusi menjamin kesatuan masyarakat adat dan hak-hak tradisionalnya dan jaminan konstitusi sepanjang hukum adat itu masih hidup sesuai dengan perkembangan masyarakat. ${ }^{1}$ Hukum adat sebagai hukum yang tidak tertulis merupakan keseluruhan adat yang tidak tertulis dan hidup dalam masyarakat berupa kesusilaan, kebiasaan, dan kelaziman yang mempunyai akibat hukum. ${ }^{2}$ Dengan sifatnya yang tidak tertulis hukum adat memiliki peraturan hidup yang meskipun tidak ditetapkan dalam hukum formal tetapi ia tetap menjadi hukum yang ditaati dan didukung oleh rakyat dengan segenap keyakinan mereka bahwasanya peraturan tersebut memiliki kekuatan hukum. $^{3}$

Sebagai negara yang mempunyai berbagai macam suku bangsa dan etnis serta kebudayaan yang beragam, Indonesia memiliki semboyan Bhinneka Tunggal Ika sebagai alat pemersatu yang disadari keberadaannya. Indonesia yang terdiri dari beriburibu pulau yang terbentang dari Sabang sampai Merauke mempunyai adat-istiadat yang berbedabeda pada masing-masing daerah. Di mana dalam hukum adat tiap-tiap lingkungan hukum adat itu memiliki ciri khas yang memberikan tanda kenal pada hukum adat yang bersangkutan sehingga bisa lebih dikenal dengan mudah. Unsur hukum adat dapat menimbulkan adanya kewajiban hukum bagi anggota masyarakat adat. Pertama, unsur kenyataan bahwa adat dalam keadaan yang sama selalu diindahkan oleh rakyat atau anggota masyarakat adat; kedua, unsur psikologis bahwa terdapat adanya keyakinan pada rakyat atau anggota masyarakat adat, bahwa adat dimaksud memiliki kekuatan hukum. ${ }^{4}$ Di samping hukum, terdapat norma-norma sosial lainnya yaitu agama, moral, dan etika tingkah laku. Norma-norma itu memberi petunjuk tentang bagaimana manusia

${ }^{1}$ Renny Magda, 2013, "Dasar Perundang-Undangan Berlakunya Hukum Adat”, http://rennymagdawiharnani. wordpress.com, diakses pada tanggal 15/01/2016.

${ }^{2}$ A. Suriyaman Mustari Pide, Hukum Adat Dahulu, Kini, dan Akan Datang, Kencana, Jakarta, 2014, h. 5.

${ }^{3}$ A. Suriyaman Mustari Pide, Ibid., h. 8.

${ }^{4}$ Ibid. bertingkah laku. Dilihat dari hubungan antara manusia dengan manusia lainnya, manusia dapat dibedakan sebagai pribadi dan sebagai komponen dalam kehidupan sosial. ${ }^{5}$ Tidak ada suatu masyarakat yang tanpa kebudayaan maka setiap masyarakat betapa pun sederhananya masyarakat itu, secara pasti memiliki nilai-nilai dan norma-norma atau kaidahkaidah. Salah satu norma yang ada dalam masyarakat yang terwujud dari perilaku yang disebut dengan norma adat dan hukum adat. Dengan demikian norma hukum adat merupakan bagian dari norma-norma masyarakat atau norma sosial. ${ }^{6}$

Kehidupan bangsa Indonesia saat ini tengah menghadapi ancaman yang berkaitan dengan mengerasnya konflik-konflik sosial dalam masyarakat baik yang bersifat vertikal maupun horizontal. Sumber konflik tersebut bisa berasal dari perbedaan nilai-nilai dan ideologi. Contoh nyata dari konflik sosial yang sering terjadi adalah konflik yang timbul dalam pergaulan umat beragama baik intern maupun antar umat beragama seperti munculnya kekerasan, perusakan rumah ibadah dan kekerasan agama lainnya yang dilakukan oleh masyarakat sipil. 7 Dengan banyaknya keanekaragaman suku, agama, ras, dan budaya Indonesia timbul banyak konflik sosial yang terjadi dalam masyarakat. Kondisi tersebut dapat membawa dampak buruk bagi kehidupan nasional, apabila terdapat kondisi ketimpangan pembangunan, ketidakadilan dan kesenjangan sosial, ekonomi, kemiskinan serta dinamika kehidupan politik yang tidak terkendali.

Penanganan konflik sosial mendasarkan pada Pasal 1 Undang-Undang Nomor 7 Tahun 2012 tentang Penanganan Konflik Sosial merupakan serangkaian kegiatan yang dilakukan secara sistematis dan terencana dalam situasi dan peristiwa baik sebelum, pada saat, maupun sesudah terjadi konflik yang mencakup pencegahan konflik, penghentian konflik, dan pemulihan pascakonflik. Undang-undang ini, dalam penanganan konflik harus mencerminkan asas kemanusiaan, hak asasi manusia, kebangsaan, kekeluargaan, mengacu pada bhineka tunggal

${ }^{5}$ Peter Mahmud Marzuki, Pengantar Ilmu Hukum, Kencana, Jakarta, 2008, h. 85.

${ }^{6}$ C. Dewi Wulansari, Hukum Adat Indonesia Suatu Pengantar, Refika Aditama, Bandung, 2010, h. 12.

${ }^{7}$ Ahmad Ubbe, 2011, "Laporan Pengkajian Hukum tentang Mekanisme Penanganan Konflik Sosial”, www.bphn.go.id/datal pkj-2011-10.pdf, diakses pada tanggal 29/05/2015. 
ika, keadilan, kesetaraan gender, ketertiban, dan kepastian hukum. Juga mencerminkan keberlanjutan, kearifan lokal, partisipatif, tidak memihak, dan tidak membeda-bedakan. Tujuan penanganan konflik sosial menurut Pasal 3 undang-undang untuk menciptakan kehidupan masyarakat yang aman, tenteram, damai dan sejahtera. Lalu memelihara kondisi damai dan harmonis dalam hubungan sosial kemasyarakatan. Meningkatkan tenggang rasa dan toleransi, memelihara fungsi pemerintahan, melindungi jiwa, harta benda, serta sarana prasarana umum. Serta memberikan perlindungan dan pemenuhan hak korban, dan memulihkan kondisi fisik dan mental masyarakat serta sarana dan prasarana umum. Undang-undang ini menyebutkan bahwa konflik dapat bersumber dari permasalahan yang berkaitan dengan politik, ekonomi, dan sosial budaya; perseteruan antar umat beragama, antar suku, dan antar etnis; sengketa sumber daya alam antar masyarakat dan/atau antar masyarakat dengan pelaku usaha, dan distribusi sumber daya alam yang tidak seimbang dalam masyarakat. Undang-Undang Nomor 7 Tahun 2012 tentang Penanganan Konflik Sosial memuat 62 pasal yang mengatur penanganan konflik sosial, penghentian konflik, dan pemulihan pascakonflik.

Salah satu contoh masalah konflik yang cukup serius merupakan konflik sosial antar agama yang terjadi di Maluku pada Tahun 1999. Konflik di Maluku pada Tahun 1999, menurut sebagian orang merupakan konflik keagamaan antara Islam dan Kristen. Konflik tersebut merupakan rantai panjang dari adanya ketidakadilan dan marjinalisasi masyarakat akibat kebijakan pemerintah baik kolonial maupun republik. Konflik yang terjadi di Maluku ini bukan hanya karena agama, tetapi juga karena perpolitikan, birokrasi, dan perekonomian, yang menyebabkan kecemburuan sosial dan pada perkembangannya menyeret agama sehingga menimbulkan konflik besar yang berkepanjangan. Konflik di Maluku pada Tahun 1999 telah menyebabkan banyak penderita bagi masyarakat Maluku, suka atau tidak konflik itu telah merobek-robek habis sebuah peradaban yang sangat tua di Indonesia yaitu kerukunan beragama; yang kata orang, di Maluku-lah tempatnya. ${ }^{8}$ Maluku khususnya di Pulau Ambon, Pulau Lease, dan Pulau

\footnotetext{
${ }^{8}$ John Pieris, Tragedi Maluku Sebuah Krisis Peradaban, Yayasan Obor, Jakarta, 2004, h. 111.
}

Seram terdapat salah satu lembaga adat yang sampai saat ini masih tetap dijaga dan dipertahankan dalam kehidupan masyarakat ambon yakni Ikatan Pela. Permasalahan konflik di Maluku menyisakan satu permasalahan tentang usaha menempatkan Pela dalam konteks hubungan Islam dan Kristen pada masyarakat di sana. Pemikiran semacam itu sebenarnya lahir dari konteks masyarakat yang memandang Pela dalam perspektif kesejarahannya. Hal penting disini merupakan perspektif untuk melihat Pela tidak saja dalam konteks hubungan antara manusia, tetapi juga melihatnya lebih jauh sebagai komunikasi yang memiliki perspektif etik, termasuk mendorong ke arah upaya membangun hubungan Islam dan Kristen. Asumsi pokoknya ialah perspektif etik yang berlaku dalam suatu masyarakat selalu memiliki basis historis dan kebudayaan dalam konteks setempat. ${ }^{9}$ Pada umumnya budaya Pela merupakan suatu tradisi yang ada pada masyarakat Maluku dalam menciptakan suatu kebersamaan dan kerukunan antara negeri Islam dengan negeri Kristen.

\section{PERUMUSAN MASALAH}

Berdasarkan uraian singkat latar belakang maka dalam rumusan masalah ini adalah Bagaimana peran Pela Gandong dalam tradisi masyarakat Maluku, serta Bagaimana cara penyelesaian konflik di Maluku melalui Pela Gandong yang dilihat dalam konteks Undang-Undang Nomor 7 Tahun 2012 tentang Penanganan Konflik Sosial.

\section{METODE PENELITIAN}

Metode yang digunakan dalam penulisan ini adalah statute approach, mengkaji tentang UndangUndang Nomor 7 Tahun 2012 tentang Penanganan Konflik Sosial, dan case approach atau pendekatan kasus penyelesaian konflik di Maluku melalui Pela Gandong.

\section{PEMBAHASAN}

\section{Pela Gandong Sebagai Sarana Penyelesaian Konflik di Maluku}

Ada satu kultur khas di ranah Maluku, khususnya di Maluku Tengah. Kultur tersebut dikenal dengan sebutan Pela Gandong yang kerap menjadi

\footnotetext{
${ }^{9}$ John Chr. Ruhulessin, Etika Publik Menggali dari Tradisi Pela di Maluku, Satya Wacana University Press, Salatiga, 2007, h. 146 .
} 
kebanggaan masyarakat Maluku sejak dulu hingga sekarang ini. Pela diartikan sebagai suatu relasi perjanjian persaudaraan antara satu negeri dengan negeri lain yang berada di pulau lain dan kadang juga menganut agama yang berbeda, sedangkan Gandong sendiri bermakna saudara. Perjanjian ini kemudian diangkat dalam sumpah yang tidak boleh dilanggar. Pada saat upacara sumpah berlangsung, campuran soppi (tuak) dan darah yang diambil dari tubuh masing-masing pemimpin negeri akan di minum oleh kedua pihak yang bersangkutan setelah senjata dan alat-alat tajam lain dicelupkan ke dalamnya. Adapun empat hal pokok yang mendasari Pela yaitu: Pertama, negeri-negeri yang berpela berkewajiban untuk saling membantu pada kejadian genting (perang, bencana alam). Kedua, Apabila diminta, maka negeri yang satu wajib memberikan bantuan kepada negeri yang lain yang hendak melaksanakan proyek kepentingan umum seperti pembangunan sekolah, masjid, atau gereja. Ketiga, Apabila seseorang sedang mengunjungi negeri yang berpela itu, maka orang-orang di negeri itu wajib untuk memberi makanan kepadanya dan tamu yang sepela itu tidak perlu meminta izin untuk membawa pulang hasil bumi atau buah-buahan yang menjadi kesukaannya karena penduduk negeri-negeri yang berhubungan Pela itu dianggap sedarah, maka dua orang yang sepela tersebut dilarang untuk menikah. ${ }^{10}$

Dari segi antropologis masyarakat asli Maluku Tengah berasal dari dua pulau besar yaitu Pulau Seram dan Pulau Buru, kemudian berimigrasi ke pulau-pulau kecil di sekitarnya. Para migran dari pulau Seram menyebar ke Kepulauan Lease/Uliaser (Pulau Haruku, Pulau Saparua, dan Pulau Nusa Laut), dan Pulau Ambon. Migrasi ini kemudian memberi dampak terhadap terjadinya asimilasi kebudayaan baru (kebudayaan Seram) yang mendapat pengaruh dari kebudayaan Melanesia, Melayu, Ternate, Tidore. Daerah Maluku Tengah memiliki satu kebudayaan yang sama kemudian jika ditelusuri dari segi historisnya para migran yang kebanyakan berdiam di pegunungan lantas dipindahkan ke pesisir pantai oleh pemerintah Belanda dalam rangka pengawasan. Bukan hanya itu, Belanda juga mengganti nama komunitas-komunitas migran yang disebut

\footnotetext{
${ }^{10}$ Ricky Yuliam Siwalette, 2012, "Sejarah Pela Gandong”, http://allangforsamua.wordpress.com, diakses pada tanggal 15 Januari 2016.
}

Hena dan Aman, dengan istilah negeri. Struktur pemerintahan di dalam negeri diatur menyerupai struktur pemerintahan Belanda. Dengan struktur pemerintahan tersebut, maka negeri-negeri menjadi negara-negara kecil dengan pemerintah, rakyat teritori tertentu, dipimpin oleh raja yang diangkat dari marga-marga tertentu yang memerintah secara turun temurun, dan kekuasaan di dalam negeri dibagi-bagi untuk seluruh marga dalam komunitas negeri.

Dalam perkembangannya secara sosio-historis, negeri-negeri ini kemudian mengelompok dalam komunitas agama tertentu, sehingga timbul dua kelompok masyarakat yang berbasis agama, yang kemudian dikenal dengan sebutan Anak Negeri Salam dan Anak Negeri Sarani. Kultur seperti ini memperlihatkan adanya suatu kecenderungan yang akan rentan terhadap kemungkinan konflik. Oleh sebab itu, dikembangkanlah Pela Gandong sebagai suatu pola manajemen konflik tradisional guna mengatasi kerentanan konflik. ${ }^{11}$

Pela seperti yang dikenal dalam masyarakat Maluku sekarang ini adalah ikatan persaudaraan yang telah melembaga antara penduduk dari dua desa atau lebih baik antara desa-desa Islam maupun antara desa Kristen dan desa Islam. Ikatan tersebut telah dibentuk oleh para leluhur atau tete-nene moyang dalam suatu keadaan khusus, serta memikul hak dan kewajiban yang terlihat dalam ikatan tersebut. ${ }^{12}$

Pemujaan Leluhur; Tete Nene Moyang atau Upu merupakan dasar yang penting untuk memahami gagasan kebaikan dalam Pela. Bila dasar ini hilang, maka hilang pula itu Pela. Pela tidak bisa dilepaskan dari penyembahan kepada leluhur. Ketika penyembahan leluhur hilang, maka tidak ada lagi jembatan yang menghubungkan Islam dan Kristen. Orang Maluku bergantung kepada leluhurnya. Leluhur merupakan sumber kebaikan tertinggi yang daripadanya mengalir kebajikan-kebajikan atau adat yang membingkai tatanan kehidupan bersama masyarakat dalam suatu totalitas yang harmonis dan utuh. ${ }^{13}$ Pela sebagai suatu bagian dari adat, memiliki seperangkat aturan yang mengikat masingmasing pribadi dalam perseketuan tersebut. Aturan ini dipahami berasal dari tete nene moyang yang

\footnotetext{
${ }^{11}$ Ibid.

12 F.L. Cooley, Altar and Thome in Central Mollucan Societies, Yale University, 1902, h. 261.

${ }^{13}$ John Chr Ruhulessin, Op.Cit., h. 253.
} 
memiliki kuasa dan kekuatan tertentu yang tidak dapat dikuasai dan dikehendaki oleh manusia, suatu kuasa yang dianggap trasenden. Trasenden kuasa para leluhur ini mengakibatkan manusia mempercayainya, sehingga pada gilirannya merupakan suatu kepercayaan.

Hal pokok yang perlu dikemukakan dalam sini bahwa Pela bukanlah suatu agama tetapi dalam ikatan Pela itu terkandung nilai-nilai agamawi yang berkaitan dengan kepercayaan kepada Tuhan sang pencipta dan para leluhur (tete-nene moyang) sebagai yang mengatur kehidupan manusia.

Pada dasarnya ada 3 (tiga) jenis Pela, yaitu Pela Darah, Pela Gandong, dan Pela Tempat Sirih. Selain ketiga jenis hubungan Pela tersebut, ada juga dua hubungan Pela lainnya yang tidak bersifat umum yaitu Pela Batu Karang dan Pela Kawin sehingga semuanya ada 5 (lima) yaitu Pela Darah, ${ }^{14}$ Pela Gandong, ${ }^{15}$ Pela Tempat Sirih, ${ }^{16}$ Pela Batu Karang, dan Pela Kawin. ${ }^{17}$

Perlu dikemukakan bahwa pembentukan Pela lebih banyak didorong inisiatif penduduk. Kenyataan ini sungguh penting terutama untuk melihat masa

\footnotetext{
${ }^{14}$ Pela Darah (Pela Karas) adalah sumpah yang diikrarkan antara dua negeri atau lebih karena terjadinya suatu peristiwa yang sangat penting dan biasanya berhubungan dengan peperangan antara lain seperti pengorbanan antara lain seperti pengorbanan, akhir perang yang tidak menentu (tak ada yang menang atau kalah perang), atau adanya bantuan-bantuan khusus dari satu negeri kepada negeri lain. Pela Karas dan Pela Gandong ditetapkan oleh sumpah yang sangat mengikat dan biasanya disertai dengan kutukan untuk pelanggaran terhadap perjanjian Pela ini. Sumpah dilakukan dengan mencampur tuak dengan darah yang diambil dari tubuh pemimpin kedua pihak kemudian diminum oleh kedua pihak tersebut setelah senjata-senjata dan alat-alat perang lain dicelupkan ke dalamnya. Alat-alat tersebut nantinya digunakan untuk melawan dan membunuh siapa pun yang melanggar perjanjian. Penukaran darah memeteraikan persaudaraan itu.

${ }^{15}$ Pela Gandong atau Bongso didasarkan pada ikatan darah atau keturunan untuk menjaga hubungan antara kerabat keluarga yang berada di negeri atau pulau yang berbeda.

${ }^{16}$ Pela Tampa Sirih, setelah suatu peristiwa yang tidak begitu penting berlangsung, seperti memulihkan damai kembali sehabis suatu insiden kecil atau bila satu negeri telah berjasa kepada negeri lain. Jenis Pela ini juga biasanya ditetapkan untuk memperlancar hubungan perdagangan. Pela Tampa Sirih dilakukan sumpah dengan menukar dan mengunyah sirih bersama. Pela Tampa Sirih merupakan suatu perjanjian persahabatan sehingga perkawinan antar pihak yang terkait diperbolehkan dan tolong-menolong lebih bersifat sukarela tanpa ada ancaman hukuman nene moyang.

${ }^{17}$ Angel, 2010, “Asal Usul Negeri Porto dan Nenek Moyang Talakua", https://willn094.wordpress.com, diakses pada tanggal 25 Nopember 2015.
}

depan Pela, menyangkut fungsi dan peranannya dalam masyarakat. Pembentukan Pela merupakan bukti yang otentik mengenai kearifan rakyat. ${ }^{18}$ Dalam membangun ikatan Pela pertama-tama pihak yang hendak berpela harus melakukan inisiasi atau ritus dengan mengucapkan sumpah yang dilakukan secara lisan oleh seorang raja, apa yang diucapkannya dianggap bersifat mengikat bagi semua warga negeri. Oleh karena itu ketaatan terhadap perjanjian juga sekaligus ketaatan terhadap kekuasaan raja dan warga masyarakat. Pelanggaran terhadap ikatan perjanjian dari warga negeri akan mendapatkan sanksi dari pemerintah negeri. ${ }^{19}$ Sanksi dalam hubungan Pela biasanya dibedakan atas 2 (dua) bagian yaitu sanksi yang kelihatan dan sanksi yang tidak kelihatan. Sanksi yang kelihatan biasanya dilakukan oleh fungsionaris hukum adat Badan Saniri Negeri sedangkan sanksi yang tidak kelihatan biasanya datang dari Tuhan dan para leluhur yang dipercayai masyarakat yang dikenal sebagai pembentuk Pela. Namun yang lebih banyak terjadi adalah sanksi yang tidak kelihatan. Bentuk sanksi yang tidak kelihatan itu berbentuk seperti guntur, kilat, angin ribut, dan hujan serta penyakit.

Sanksi ini dianggap oleh masyarakat setempat sebagai kutukan Tuhan dan para leluhur atau tete nene moyang. Apabila kondisi ini tidak dikembalikan ke keadaan semula, maka hal ini bisa berakibat kematian. Sanksi ini muncul ketika ada sesuatu yang tidak beres antara kedua negeri yang berpela, misalnya pelanggaran terhadap butir-butir kesepakatan yang terdapat dalam aturan dan norma-norma Pela. Untuk menyelamatkan masyarakat dari sanksi-sanksi itu, maka pihak yang memulai konflik biasanya yang memohon agar secepatnya melakukan Panas Pela untuk membuat situasi kembali normal.

Aspek lain yang penting juga adalah makna dari hubungan sebagai saudara pela yang telah membantu secara efektif meruntuhkan kebekuankebekuan tentang pemaknaan untuk hidup bersama, yang diakibatkan pengalaman historis yang tragis telah memisahkan keduanya. Ikatan sebagai anggota Pela telah menempatkan masing-masing anggota Pela sebagai saudara yang harus dihormati. Posisi keduanya setara bahkan seringkali masing-masing

\footnotetext{
${ }^{18}$ John Chr Ruhulessin, Op.Cit., h. 175.

${ }^{19}$ Ibid.
} 
memperlakukan saudara Pelanya lebih khusus dibanding kepada kelompok klannya. ${ }^{20}$

Ritus-ritus yang sering dilakukan di dalam masyarakat Maluku adalah ritus Panas Pela, tidak sebatas menunjuk pentingnya suatu peristiwa seremonial. Dimensi seremonial tetap ada dalam setiap ritus, tetapi inti dari pengulangan penyelenggaraan ritus Panas Pela merupakan penegasan dan pembaruan janji antar negeri berpela. Bila dikaji dari segi sejarah maka Panas Pela pada prinsipnya merupakan kelanjutan dari angkat Pela. Hal ini merupakan manifestasi dari pemikiran masyarakat untuk selalu dan senantiasa menyiapkan sarana lain yang sifatnya bisa dijadikan sebagai sarana penyelesaian, mengantisipasi kemungkinan konflik yang terjadi antar desa atau negeri-negeri yang berpela. Panas Pela merupakan sarana atau media baku dapa atau bertemu antar kedua negeri yang berpela untuk membicarakan dan menyelesaikan berbagai persoalan hidup di antara mereka demi untuk lebih mengkokohkan hubunganhubungan Pela di antara mereka. Panas Pela juga merupakan suatu kegiatan ritual masyarakat pada saat tertentu hal ini selalu dilaksanakan. Ada desa atau negeri yang menyepakati agar 4 (empat) tahun sekali dilaksanakan Panas Pela, ada juga Panas Pela dilakukan 3 (tiga) tahun sekali. Namun keputusan ini bisa saja berubah kalau ada permintaan dari salah satu pihak, terkait dengan persoalan-persoalan yang muncul dalam masyarakat.

Alasan diadakannya Panas Pela tersebut adalah untuk menyelesaikan berbagai persoalan-persoalan yang terjadi, terkait dengan pelanggaran-pelanggaran yang dibuat oleh kedua masyarakat. Lewat Panas Pela ini masyarakat didamaikan dan disatukan kembali untuk selalu dan senantiasa menjaga hubungan baik di antara mereka. Panas Pela bagi generasi muda dari kedua negeri perlu dilakukan untuk tetap menjaga apa yang sudah dibuat oleh para leluhur mereka demi tercapainya ketertiban dan keamanan dalam masyarakat.

Salah satu contoh dalam kenyataan bahwa terdapatnya negeri-negeri di Ambon yang melakukan Pela, yaitu Batu Merah untuk Islam dan Passo untuk Kristen. Mulai awal kerusuhan 19 Desember 1999 sampai 25 April 2005 semua kejadian tragis yang terjadi di Ambon dengan segala dampaknya di bidang

${ }^{20}$ John Chr Ruhulessin, Op.Cit., h. 177. kehidupan beragama, kehidupan ekonomi-sosial, politik. Masyarakat umum dan masyarakat dalam ikatan Pela umumnya geram dan marah. Kedua belah pihak Islam dan Kristen marah dengan pusat perhatian pada kasus sepele pemalakan uang dari sopir angkot jurusan Batu Merah-Pasar Kota Ambon. Waktu itu pemisahan kelompok agama Islam dan Kristen belum terpecah khususnya dalam ikatan Pela antara Desa Batu Merah (Islam) dan Passo (Kristen). Ikatan Pela kedua ini desa ini penting karena Desa Batu Merah adalah pintu masuk jalan darat satu-satunya ke dan dari Kota Ambon. Demikian juga Desa Passo adalah desa yang menjadi pintu masuk jalan darat bagi semua kendaraan dari jalur angkutan dari dan ke jasirah Leihitu. Di daerah ini beragama Muslim, yaitu desa-desa Hitu, Hila, Mamala, Morela, Wakal, Seit, Ureng, Asilulu, Wakasihu, Larike, dan Negeri Lima. Passo juga menjadi pintu masuk dan keluar kendaraan dari Desa Tulehu (Islam), Desa Wa'ai (Kristen) dan Desa Liang (Islam). Desa Tulehu adalah pelabuhan pendaratan penumpang dari pulau-pulau Lease dan Masohi, sedangkan Desa Liang adalah pelabuhan pendaratan Kapal Ferri yang menghubungkan Pulau Seram dan Pulau Ambon. Setelah kerusuhan berjalan sekitar 2 (dua) bulan, pemecahan kelompok Islam dan Kristen mulai merebak. Terjadinya penyerangan dengan pemusnahan rumah penduduk, penangkapan, penyanderaan, dan pembantaian. Sampai tahun pertama kerusuhan, kedua saudara Pela Batu Merah dan Passo masih saling melindungi sesama saudaranya, ini dilihat dari penghadangan kendaraan dari luar kota yang harus melewati Batu Merah bisa bebas lewat sebab itu kendaraan penumpang milik orang Passo. ${ }^{21}$

Menjadi sangat jelas bahwa ikatan sebagai anggota Pela telah menempatkan masing-masing anggota Pela sebagai saudara yang harus dihormati. Posisi keduanya setara bahkan seringkali saudara Pelanya diperlakukan lebih khusus dibandingkan kelompok klennya. Masyarakat berpela memandang saudara Pelanya sebagai individu yang keberadaannya setara dengan dirinya. Tindakan yang ditujukan kepada saudara Pela selalu ditempatkan dalam pangandaian ketika perilaku itu ditujukan kepada diri sendiri. Perhatian terhadap sekutu Pela lebih

${ }^{21}$ Nicodemus Sedubun, 2014, "Pela di Maluku Tengah", http://ohoi-ra.wordpress.com/2014/05/pela-di-maluku-tengah. com, diakses pada tanggal 01 Desember 2015. 
dilihatnya sebagai manusia yang utuh, yang memiliki kualifikasi kemanusiaan yang sama dengan yang lain. Ini adalah suatu cara berpikir etik yang tanggung jawab. $^{22}$

Menjadi sangat jelas bahwa ikatan sebagai anggota Pela telah menempatkan masing-masing anggota Pela sebagai saudara yang harus dihormati. Posisi keduanya setara bahkan seringkali saudara Pelanya diperlakukan lebih khusus dibandingkan kelompok klennya. Masyarakat berpela memandang saudara Pelanya sebagai individu yang keberadaannya setara dengan dirinya. Tindakan yang ditujukan kepada saudara Pela selalu ditempatkan dalam pangandaian ketika perilaku itu ditujukan kepada diri sendiri. Perhatian terhadap sekutu Pela lebih dilihatnya sebagai manusia yang utuh, yang memiliki kualifikasi kemanusiaan yang sama dengan yang lain. Ini adalah suatu cara berpikir etik yang tanggung

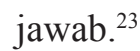

Pada hakikatnya Pela telah mengandung unsur rekonsiliasi. Oleh karena dalam budaya Pela itu sendiri dinyatakan bagaimana ikatan yang kuat dalam menjalin kedamaian atau kehidupan yang saling merasakan susah dan dan senang secara bersama.

\section{Proses-Proses Terjadinya Konflik di Maluku}

Pada taraf tertentu, masyarakat Maluku sebagaimana juga masyarakat-masyarakat lainnya di Indonesia, sedang mengalami perubahan dan perkembangan memasuki masyarakat modern. Modernisasi sebagai sebuah proses perubahan mencakup dimensinya yang luas. Salah satunya adalah perkembangan rasionalitas. Rasionalitas ini terwujud dalam berbagai bentuk, seperti dalam sosok birokrasi. Rasionalisasi yang terjadi dalam masyarakat, terutama di masyarakat desa atau negerinegeri adat, telah mencuatkan persoalan-persoalan baru. ${ }^{24}$ Suatu negeri merupakan persekutuan teritorial yang terdiri dari beberapa soa yang pada umumnya berjumlah paling sedikit tiga buah. Istilah negeri masyarakat Maluku telah menerima dan mempertahankannya sebagai kebudayaan dan terdapat rasa keterpanggilan serta pengorbanan pada negeri asalnya masing-masing. Peraturan Daerah Propinsi Maluku Nomor 14 Tahun 2005

\footnotetext{
22 John Chr Ruhulessin, Op.Cit., h. 260

${ }^{23}$ John Chr Ruhulessin, Op.Cit., h. 260.

${ }^{24}$ John Chr Ruhulessin, Op.Cit., h. 18.
}

merumuskan negeri merupakan kesatuan masyarakat hukum adat yang memiliki batas-batas wilayah, yang berwenang untuk mengatur dan mengurus kepentingan masyarakat setempat berdasarkan asal usul, adat istiadat, dan hukum adat setempat, diakui dan dihormati dalam sistem Pemerintahan Negara Kesatuan Republik Indonesia. ${ }^{25}$

Cara hidup orang Maluku yang cinta damai sesuai nilai budaya yang dimiliki, pada waktu-waktu tertentu mengalami ujian berat dalam bentuk konflikkonflik yang terjadi di antara mereka. Hal tersebut terjadi karena kehidupan orang Maluku bukanlah kehidupan yang statis, tetapi kehidupan yang dinamis yang saling mempengaruhi dengan berbagai gejolak masyarakat di Indonesia sebagai bagian dari suatu masyarakat negara dan juga sebagai bagian dari warga masyarakat internasional.

Konflik Maluku mulai terjadi pada tanggal 19 Januari 1999 berjalan dalam beberapa tahun, dapat dipandang sebagai suatu proses sosial yang disosiatif dengan tingkat kekerasan yang sangat tinggi dan memakan korban yang sangat banyak. Sebut saja Kepala Kepolisian Republik Indonesia, waktu awal konflik menyebut penyebab konflik Maluku dimulai dari kasus Batu Merah adalah kriminal murni. Kronologi konflik di Maluku dapat dibagi menjadi beberapa tahapan. Tahapan pertama mulai tanggal 19 Januari 1999, kedua sejak 24 Juli 1999, dan tahapan ketiga sejak 26 Desember 1999, mungkin juga kedatangan Laskar Jihad pada Mei 2000 dapat dijadikan sebagai tahapan keempat. Tahapan pertama dimulai pada tanggal 19 januari 1999, pada tanggal tersebut terjadi suatu pertikaian antara seorang supir angkot dengan seorang preman di terminal bis Batu Merah. Kerusuhan tersebut segera cepat meluas menjadi konflik antara orang Islam dan orang Kristen yang ada di wilayah Batu Merah dan Galunggung. Keesokan harinya terjadi kebakaran di berbagai sudut kota Ambon. Gereja Maranatha sebagai pusat pemuda Kristen berikat kepala merah sedangkan Masjid Al Fatah sebagai pusat pemuda Islam berikat kepala putih.

Dalam peristiwa tersebut orang dagang (Bugis, Buton, Makasar) yang paling menderita karena tempat usaha mereka di pasar rusak dan bakar. Sejak saat itu konflik senjata terus berlangsung siang malam. Pada

${ }^{25}$ Semuel Waileruny, Membongkar Konspirasi di Balik Konflik Maluku, Yayasan Pustaka Obor, Jakarta, 2010, h. 94. 
tanggal 14 Februari terjadi serangan oleh orang Islam di Pulau Haruku terhadap orang Kristen di pulau itu juga. Keadaan semakin memanas pada bulan Maret 1999. Pada 1 Maret terjadi insiden di Masjid Ahuru di mana beberapa anggota Polri dituduh melakukan pembunuhan terhadap orang Islam yang sedang sholat. Walaupun hal ini tidak benar tetapi berita tentang hal tersebut sudah terdengar di Jakarta yang mengakibatkan demonstrasi oleh umat Islam. Kemudian pada tanggal 31 Maret 1999 kerusuhan yang terjadi semakin meluas ke Tual yang merupakan bagian dari Kepulauan Kei, dan pada tanggal 19-20 April konflik juga meluas ke Kepulauan Banda. Tanggal 20 Juni terjadi juga di Waab, Kei Kecil. Lalu pada tanggal 15 Juli terjadi konflik antara negeri Kristen Ulat dengan negeri Islam Sirisori di Pulau Saparua.

Tahapan kedua dimulai pada tanggal 24 Juli 1999. Konflik kedua ini bermula dari kerusuhan yang terjadi di daerah Poka Kotamadya Ambon yang selanjutnya menjalar ke kota Ambon. Pada hari pertama terjadi pembakaran di seluruh pusat ekonomi milik Cina sehingga mereka mengungsi dari Ambon. Pada tahapan kedua ini mereka sudah menggunakan senjata api rakitan. Pada Agustus 1999 sejumlah aparat keamanan menyerang dan membakar Gereja Galala bersama umat yang ada di dalamnya. Lalu pada tanggal 18 dan 19 Agustus beberapa daerah Islam menyerang daerah Kristen Piru dan berulang lagi pada 2 Desember. Konflik antar aparat kembali lagi pada 3 Oktober di Batu Merah. Konflik besar-besaran terjadi di Ambon antara 26 sampai 30 Oktober 1999. Konflik periode kedua juga terjadi pada saat Pemilu tahun 1999 yang pada waktu itu dimenangkan oleh PDIP. Partai tersebut memiliki kedekatan dengan pemilik yang notabene beragama Kristen karena merupakan gabungan dari Parkindo, PNI, dan Partai Nasionalis lainnya yang memiliki basis kuat di Maluku. Kemenangan PDIP tersebut disambut baik oleh komunitas Kristen dan mereka berharap bisa memperoleh kembali kursi di birokrasi melalui PDIP. Kekalahan Golkar maupun partai Islam lainnya yang pada umumnya didukung oleh komunitas Islam telah memunculkan kembali bibit-bibit konflik di Maluku. Ironisnya justru konflik Maluku yang semula hanya bentrokan dua negeri kini telah memperlihatkan keterlibatan aparat keamanan sebagai aktor lain dalam kerusuhan agama tersebut.
TNI yang dekat Golkar sebagai partai pemerintah dianggap lebih memihak Islam, sementara polisi dekat dengan Kristen dengan keadaan seperti ini sudah pasti aparat keamanan tidak bisa melaksanakan tugasnya dengan baik.

Tahapan ketiga dimulai pada tanggal 26 Desember 1999. Konflik ketiga ini berawal ketika terjadi pembakaran rumah-rumah ibadah baik kaum Kristen maupun Islam yaitu Gereja Silo dan Masjid An-Nur. Peristiwa ini memicu konflik di luar kota Ambon yaitu Masohi, Seram. Dalam konflik ketiga ini para perusuh sudah menggunakan senjata organik milik aparat keamanan. Hal ini dapat terjadi kemungkinan jika ada pihak luar Indonesia yang membantu konflik dalam hal persenjataan. Meluasnya konflik tersebut menyebabkan adanya kasus ABRI, Letjen Marasabessy menurunkan tidak kurang dari 18 Batalyon untuk mengamankan Maluku Tengah dan Maluku Utara pada bulan Maret. Pada saat itu, setiap hari diadakan razia senjata, memperlakukan jam malam dan perintah tembak di tempat dikeluarkan. TNI AL juga tidak ketinggalan dengan mengerahkan 5 kapal pengintai untuk mengadakan patroli di perairan di Maluku Utara dan Maluku Tengah.

Tahapan keempat yaitu dimulai dengan masuknya Laskar Jihad. Periode keempat konflik anarkisme agama di Maluku yaitu adanya aktor luar Maluku yang ikut "berpartisipasi" dalam konflik tersebut. Adalah masuknya Laskar Jihad ke Maluku yang dipimpin oleh Ja'far Umar Thalib dengan 10.000 pasukan menyebabkan ketidakseimbangan kekuatan antara kelompok Islam dan Kristen. Mereka merupakan pasukan yang memang sengaja dibentuk, dipersiapkan dengan dibekali pelatihan kemiliteran sebelumnya, dilengkapi senjata yang lebih modern dan memiliki dukungan dana yang kuat. Laskar Jihad menilai bahwa ketertindasan umat Muslim di Maluku karena ulah dari kaum salibis yang tidak menyukai Islam. Maka terdorong semangat jihad untuk membantu saudara seiman sebagai jiwa korsa, Laskar Jihad mulai melakukan penyerangan terhadap kelompok-kelompok Kristen di bawah komando Alex Manuputty melalui Front Kedaulatan Maluku (yang selanjutnya disebut dengan FKM) yang memiliki afiliasi dengan RMS. Kondisi konflik berjalan tidak seimbang terlebih tuduhan afiliasi FKM dengan RMS merupakan gerakan separatisme memberikan angin besar untuk menekan kelompok Kristen. Kondisi 
konflik yang makin beringas dan menjalar ke luar Ambon. Hal ini kemudian mendorong tokoh-tokoh lintas agama mengadakan pertemuan perdamaian yang menghasilkan Perjanjian Malino II sebagai konsensus kesepakatan perdamaian di Maluku.

\section{Peran Serta Hukum Adat dalam Aspek Kebudayaan}

Hukum adat merupakan bagian yang tak terlepaskan dari sebuah kebudayaan masyarakat indonesia. Jauh sebelum penerapan hukum kolonial di Indonesia, masyarakat nenek moyang kita sudah menganut sistem hukum tersendiri. Meski hukum adat yang berlaku di Indonesia dengan unsur kebudayaan lebih bersifat lokal dibanding hukum kolonial yang sifatnya universal, tetapi di balik kelokalannya hukum adat mampu mengakomodasi bahkan memperutuh sifat kebhinekaan bangsa ini. ${ }^{26}$ Selanjutnya, adat dalam kebudayaan terbagi atas empat tingkatan, yaitu: Nilai Budaya, Nilai Norma, Tingkat Hukum, dan Aturan hukum. ${ }^{27}$

Dengan demikian, tidak ada masyarakat tanpa kebudayaan. Maka, betapa pun sederhananya masyarakat itu, setiap masyarakat secara pasti memiliki nilai-nilai dan norma-norma atau kaidahkaidah. Salah satu norma yang ada dalam suatu masyarakat ialah norma yang terwujud dari perilaku masyarakat yang dilakukan secara berulang-ulang dalam pola perilaku yang sama, yang dikenal dengan norma adat dan hukum adat. Dengan demikian norma atau hukum adat merupakan bagian dari normanorma masyarakat. ${ }^{28}$

Hukum adat merupakan suatu aktivitas di dalam rangka suatu kebudayaan yang mempunyai fungsi pengawasan sosial. Pengawasan sosial yang dimaksudkan meliputi: Pertama, Ciri otoritas atau Attribute of Authority. ${ }^{29}$ Menentukan bahwa aktivitas-aktivitas kebudayaan yang disebut hukum merupakan keputusan-keputusan melalui suatu mekanisme yang diberi kuasa dan pengaruh dalam masyarakat, keputusan itu memberi pemecahan terhadap ketegangan sosial. Kedua, Ciri kelembagaan atau Attribute of Intention of Universal Application. Keputusan ini dari pihak berkuasa itu harus

\footnotetext{
${ }^{26}$ A. Suriyaman Mustari Pide, Op.Cit., h. 20.

27 Ibid., h. 21.

28 Ibid., h. 22.

${ }^{29}$ Ibid.
}

dimaksudkan sebagai keputusan yang mempunyai jangka waktu panjang dan harus dianggap berlaku terhadap peristiwa-peristiwa yang serupa dalam masa yang akan datang. Ketiga, Ciri kewajiban atau Attribute of Obligation. Bahwa keputusan dari pemegang kuasa harus mengandung rumusan dan hak kewajiban dari individu-individu yang hidup. Keempat, Ciri penguat atau Attribute of Sanction, bahwa keputusan dari pihak yang memegang kuasa harus dikuatkan dengan sanksi. ${ }^{30}$

Hukum adat dapat dikatakan sebagai salah satu bentuk budaya hukum yang oleh masyarakat secara turun temurun digunakan untuk mengatur pedoman hidup dalam suatu masyarakat hukum adat. Kehidupan masyarakat hukum adat terikat oleh solidaritas akan persamaan kepentingan dan kesadaran. Sebagai budaya hukum, hukum adat merupakan formulasi aturan yang pembentukannya tanpa melalui legislatif, melainkan lahir dari opiniopini populer dan diperkuat oleh sanksi yang bersifat kebiasaan. ${ }^{31}$

Dengan bentuknya sebagai kebiasaan itulah maka budaya hukum yang ada dalam suatu masyarakat hukum adat cenderung berbentuk tidak tertulis atau unwritten law. Karakter lain dari budaya hukum dalam suatu masyarakat adat adalah hukum yang berlaku senantiasa mempertimbangkan dan memperhatikan kondisi psikologi anggota masyarakat, sehingga substansi fungsi dari aplikasi ketaatan akan hukum didasari atas rasa keadilan dan rasa butuh hukum dalam masyarakat. ${ }^{32}$ Suatu sistem biasanya merupakan suatu tatatan yang teratur yang terdiri dari berbagai unsur, satu sama lainnya secara fungsionalnya saling bertautan, sehingga dapat memberikan suatu pengertian. Demikian pula halnya dengan suatu sistem hukum, karena tiap-tiap hukum pada hakikatnya merupakan suatu sistem, yaitu peraturan-peraturannya merupakan suatu kebulatan berdasarkan atas kesatuan alam pikiran yang membentuknya. ${ }^{33}$

Begitu pula dengan sistem hukum adat, identitas hukumnya akan tumbuh dengan identitas masyarakat yang membentuknya. Oleh karena itu hukum adat merupakan suatu sistem hukum yang dibentuk

\footnotetext{
${ }^{30}$ Ibid., h. 24.

${ }^{31}$ Ibid., h. 25.

${ }^{32}$ Ibid.

${ }^{33}$ C. Dewi Wulansari, Op.Cit., h. 21.
} 
berdasarkan sifat, pandangan hidup dan cara berpikir masyarakat bangsa Indonesia yang berbeda dengan alam pikiran barat atau Eropa yang melahirkan sistem hukum dengan dasar alam pikiran atas..$^{34}$

\section{Penyelesaian Konflik di Maluku Melalui Pela Gandong}

Keanekaragaman suku, agama, ras, dan budaya Indonesia pada satu sisi merupakan suatu kekayaan bangsa yang secara langsung atau pun tidak langsung dapat memberikan kontribusi positif bagi upaya menciptakan kesejahteraan masyarakat. Namun pada sisi lain, kondisi tersebut dapat membawa dampak buruk bagi kehidupan nasional apabila terdapat ketimpangan pembangunan, ketidakadilan, dan kesenjangan sosial dan ekonomi. Kondisikondisi itu menyebabkan timbulnya konflik terutama konflik yang bersifat horizontal. Konflik tersebut terbukti telah mengakibatkan hilangnya rasa aman, timbulnya rasa takut masyarakat, kerusakan lingkungan, kerugian harta benda, korban jiwa dan trauma psikologis. Sistem penanganan konflik yang dikembangkan selama ini lebih mengarah pada penanganan yang bersifat militeristik dan represif. Berbagai upaya penanganan konflik terus dilakukan berdasarkan peraturan perundangan-undangan yang ada.

Konflik sebagai suatu realitas sosial yang sifatnya menyeluruh dan melibatkan seluruh komponen dalam masyarakat, dengan demikian mesti dibedah sebagai seluruh proses bermasyarakat dalam regional dan global, baik sebagai komunitas sosial, budaya, ekonomi, agama maupun politik. Konflik terbuka, apalagi yang melibatkan massa yang banyak dengan penggunaan kekerasan secara pasif dan menyeluruh, tidak bisa serta merta terjadi. Harus terdapat prakondisi yang memungkinkan dan mencukupi bagi terjadinya konflik yang demikian. Konflik terbuka yang terjadi secara massal dengan menggunakan simbol-simbol agama di Maluku, tentunya juga tidak serta merta terjadi. Meskipun ada provokator yang membakar massa untuk tujuan dan kepentingannya, namun tindakan tersebut hanya efektif jika memang terdapat prakondisi yang memungkinkan dan mencukupi bagi terjadinya konflik tersebut. ${ }^{35}$ Kesenjangan dan perampasan itu

\footnotetext{
${ }^{34}$ Ibid., h. 22.

35 John Pieris, Op.Cit., h. 4.
}

kemudian berkembang dan menimbulkan frustasi dan ketidakpuasan kolektif. Frustasi dan ketidakpuasan kolektif inilah yang merupakan faktor yang memungkinkan, dan jika sampai pada tingkat yang mencukupi, meledak dalam berbagai bentuk tindak kekerasan kolektif; misalnya: kekacauan, kerusuhan, konspirasi, teror, perang saudara, kudeta dan makar. ${ }^{36}$ Dari berbagai pemaparan terhadap konflik dan analisanya menurut para ahli, paling tidak dipetakan 4 faktor penyebab terjadinya konflik antara Salam dan Sarani di Maluku. ${ }^{37}$

Pertama, penyebab konflik merupakan faktor politik. Pandangan tersebut menyatakan bahwa konflik yang terjadi antara Muslim dan Kristen di Maluku erat kaitannya dengan kepentingan atau rekayasa elit politik baik di tingkat pusat maupun di tingkat lokal. ${ }^{38}$ Bahwa kerusuhan yang terjadi di Maluku termasuk di beberapa daerah lainnya seperti Aceh dan Timor tidak dapat dipisahkan dari situasi dan pengaruh perpolitikan pada tataran elit politik di tingkat pusat maupun di daerah.

Kedua, konflik di Maluku terkait dengan faktor ekonomi. Pandangan ini salah satunya dikemukakan oleh J. Manuputty. ${ }^{39}$ Menurutnya, tidak merata proses pembangunan dari pemerintah pusat menyebabkan sebagian besar masyarakat hidup dalam kemiskinan dan keterbelakangan. Tingginya angka ketergantungan dari pemerintah lokal terhadap pemerintah pusat yang bersifat sentralistik menimbulkan kesenjangan ekonomi antar wilayah dan masyarakat semakin melebar. ${ }^{40}$ Krisis ekonomi yang terjadi pada tahun 1999 dan kerusuhan semakin mempertajam kesenjangan ini. ${ }^{41}$

\footnotetext{
${ }^{36}$ Ibid., h. 5.
}

37 Salam menunjuk kepada masyarakat yang beragama Muslim, dan Sarani menunjuk kepada masyarakat yang beragama Kristen.

38 Stokhof dan Murni Jamal (ed), Konflik Komunal di Indonesia Saat Ini, INIS, Jakarta, 2003, h. 71. bandingkan John Piris, Tragedi Maluku: Sebuah Krisis Peradaban, Jakarta, Yayasan Obor Indonesia, Jakarta, 2004, h. 154.

39 J. Manuputty, "Konflik Maluku" dalam Lambang Trijono (ed), Potret Retak Nusantara, Studi Kasus terhadap Konflik di Indonesia, CSPS Books, Yogyakarta, 2004, h. 79.

${ }^{40}$ Ibid., bandingkan Lambang Triyono, Keluar dari Kemelut Maluku, Pustaka Pelajar, Yogyakarta, 2001, h. 21.

41 Salah satu isu konflik etnis antar Ambon asli dan Ambon pendatang saat dibakarnya Pasar Batu Merah (lokasi Muslim) turut juga berakar pada kesenjangan sosial-ekonomi. Lambang Trijono, Keluar dari Kemelut Maluku, Pustaka Pelajar, Yogyakarta, 2001, h. 43. 
Ketiga, faktor budaya. Hal ini terkait dengan kebijakan pembangunan yakni pemberlakuan UU No. 4 Tahun 1974 tentang Pokok-pokok Pemerintahan Daerah dan UU No. 5 Tahun 1979 tentang Sistem Pemerintahan Desa turut menciptakan guncangan kebudayaan akibat perubahan radikal, struktur dan tatanan masyarakat adat. ${ }^{42} \mathrm{Hal}$ ini didukung pula oleh pesatnya perkembangan ilmu dan teknologi sehingga melemahnya sistem adat dan terjadi pergeseran nilai dan perilaku masyarakat tereliminasi dari budayanya.

Keempat, faktor agama. Pandangan ini mengatakan konflik Maluku sebagai konflik agama. Salah satunya Suedy Marasabessy yang mengatakan bahwa pada saat konflik, agama sangat berperan menjadi pemicu dalam melanggengkan terjadinya konflik yang berkepanjangan. ${ }^{43}$ Bahkan jika dibandingkan dengan isu-isu lainnya, isu konflik agama merupakan salah satu isu yang dominan sehingga mengkondisikan masyarakat berhadaphadapan dan saling membantai. ${ }^{44}$ Simbol-simbol agama digunakan sebagai alat untuk saling menyerang satu dengan yang lainnya. Militansi pembelaan terhadap agama dikedepankan sebagai justifikasi untuk membantai komunitas yang beragama lain bahkan penafsiran-penafsiran Kitab Suci digunakan untuk membangun klaim-klaim pembenaran terhadap keharusan perang suci. ${ }^{45}$

\section{Ruang Lingkup Penanganan Konflik Berdasarkan Undang-Undang Nomor 7 Tahun 2012}

Berdasarkan Undang-Undang Nomor 7 Tahun 2012 tentang Penanganan Konflik Sosial dalam Pasal 3 menjabarkan bahwa tujuan dari penanganan konflik: Menciptakan kehidupan masyarakat yang aman, tentram, damai, dan sejahtera; Memelihara kondisi damai dan harmonis dalam hubungan sosial kemasyarakatan; Meningkatkan tenggang rasa dan toleransi dalam kehidupan bermasyarakat dan bernegara; Memelihara keberlangsungan fungsi pemerintahan; Melindungi jiwa, harta, benda, serta sarana dan prasarana umum; Memberikan perlindungan dan pemenuhan hak korban; dan

\footnotetext{
42 J. Manuputty, Op.Cit., h. 85.

${ }^{43}$ Suedy Marasabessy (ed), Maluku Baru, Jakarta, 2002, h. 33 .

${ }^{44}$ J. Manuputty, "Konflik di Maluku” dalam Lambang Trijono (ed), Potret Retak Nusantara, Studi Kasus terhadap Konflik di Indonesia, CSPS Books, Yogyakarta, 2004, h. 130. ${ }^{45} \mathrm{Ibid}$.
}

Memulihkan kondisi fisik dan mental masyarakat serta sarana dan prasarana umum.

Di dalam Pasal 4 yang tersebut pada undangundang terdapat 3 (tiga) ruang lingkup penanganan konflik meliputi Pencegahan konflik, Penghentian konflik, dan Pemulihan pasca konflik. Pencegahan konflik bertujuan untuk mencegah timbulnya kekerasan dalam konflik dan meredam potensi konflik serta mengembangkan sistem penyelesaian perselisihan secara damai. Dalam upaya untuk menjamin suasana damai dalam suatu masyarakat adanya proses-proses sosial yang dapat berlangsung tanpa hambatan, berdampak pada percepatan laju pembangunan mengakibatkan keadilan, kesejahteraan, dan kemakmuran masyarakat dapat dinikmati. Untuk itu damai atau perdamaian dapat dirumuskan sebagai suatu situasi tanpa kekerasan yang berdampak pada rasa aman secara fisik dan tenteram secara batin dan jiwa yang dinikmati manusia. Dalam mengembangkan sistem penyelesaian perselisihan secara damai: 1. Penyelesaian perselisihan dalam masyarakat dilakukan secara damai; 2. Penyelesaian secara damai ini mengutamakan musyawarah untuk mufakat; 3. Hasil musyawarah mufakat ini mengikat para pihak.

Pandangan yang dikembangkan oleh John Locke dan Rousseau agak berbeda dengan pandangan Thomas Hobbes mengenai keadaan manusia sebelum adanya negara. John Locke dan Rousseau berpandangan bahwa kehidupan manusia sebelum terbentuknya negara sebagai suatu suasana yang tentram, aman, dan damai. Rousseau menyebut bahwa pada saat lahirnya itu sebagai kertas putih. ${ }^{46}$

Bertolak dari pandangan kedua ahli tersebut maka dapat disebutkan bahwa damai sebagai suatu realitas sosial dari kehidupan manusia (selain konflik) telah ada sejak awal mula kehidupan manusia sebelum terbentuknya negara dan terus ada dalam sejarah manusia. ${ }^{47}$ Sebagaimana disebutkan bahwa damai merupakan suatu situasi yang di dalamnya terdapat keadaan yang aman dan tentram, kelegaan, sukacita, persahabatan, persekutuan, kerukunan, senang dan sebagainya yang dianggap baik dan indah dalam hidup manusia bahwa semua manusia ingin hidup di dalamnya, maka untuk mencapai suasana

\footnotetext{
${ }^{46}$ M. Solly Lubis, Ilmu Negara, 1990, h. 32.

${ }^{47}$ Semuel Waileruny, Op.Cit., h. 37.
} 
itu yang dibutuhkan perencanaan dan pelaksanaan perdamaian. ${ }^{48}$

Mekanisme pranata adat dan/atau pranata sosial menurut Undang-Undang Nomor 7 Tahun 2012 tentang Penanganan Konflik Sosial ini diatur dalam Pasal 41 yakni: pertama, Penyelesaian konflik dilaksanakan oleh Pemerintah dan Pemerintah Daerah dengan mengedepankan pranata adat dan/atau pranata sosial yang ada dan diakui keberadaannya; kedua, Pemerintah dan Pemerintah Daerah mengakui hasil penyelesaian konflik melalui mekanisme pranata adat dan/atau pranata sosial; ketiga, Hasil kesepakatan penyelesaian konflik melalui mekanisme pranata adat dan/atau pranata sosial sebagaimana dimaksud pada ayat (1) memiliki kekuatan yang mengikat bagi kelompok masyarakat yang terlibat dalam konflik; keempat, Dalam hal penyelesaian konflik melalui mekanisme pranata adat dan/atau paranata sosial sebagaimana dimaksud pada ayat (1) tidak dapat diselesaikan, maka penyelesaian konflik dilakukan oleh satuan tugas penyelesaian konflik sosial; kelima, Penyelesaian konflik melalui mekanisme pranata adat dan/atau pranata sosial sebagaimana dimaksud pada ayat (1) difasilitasi oleh Pemerintah Daerah kabupaten/kota dengan melibatkan aparatur Kecamatan dan Kelurahan atau Desa setempat.

Sebagaimana sudah dijabarkan dalam Pasal 41 mengenai mekanisme pranata adat pemerintah mengakui hasil penyelesaian konflik melalui mekanisme pranata adat. Hasil dari keputusan adat pun merupakan salah satu penyebab konsistensi dari masyarakat terhadap aturan-aturan adat yang harus ditaati, juga pilihan untuk perangkat yang akan menyelesaikan konflik di antara masyarakat. Banyak upaya yang dilakukan oleh Pemda Maluku untuk menyelesaikan konflik yang terjadi, sehingga pada akhirnya Pela Gandong yang dijadikan sebagai alat pemersatu antara umat Islam dan umat Kristen. Cara seperti inilah yang telah memiliki akar dan dilaksanakan olen masyarakat Maluku sejak ratusan tahun silam, diawali para leluhur dan kemudian secara turun-temurun berlaku sampai sekarang.

Peran Serta Kelembagaan Pranata Adat Dalam Penyelesaian Konflik di Maluku

Dalam Undang-Undang Nomor 7 Tahun 2012 tentang Penanganan Konflik Sosial Pasal 40

${ }^{48}$ Ibid. menjelaskan bahwa Kelembagaan penyelesaian Konflik terdiri atas Pemerintah, Pemerintah Daerah, Pranata Adat atau Pranata Sosial, serta Satuan Tugas Penyelesaian Konflik Sosial. Salah satu kelembagaan yang digunakan dalam menyelesaikan konflik di Maluku ialah pranata adat. Pranata Adat adalah lembaga yang lahir dari nilai adat yang dihormati, diakui, dan ditaati oleh masyarakat. Lembaga yang masih digunakan atau masih dipercaya oleh masyarakat Maluku hingga saat ini adalah Pela. Pela sebagai suatu sistem sosial dalam budaya masyarakat Maluku mengandung di dalamnya spirit dan nilai dasar kehidupan bersama. Pela adalah suatu bentuk perjanjian etik yang diikat antara kelompok masyarakat satu negeri dengan negeri lainnya. Aspek perjanjian disini menempatkan Pela sebagai suatu institusi etik yang sejak awal telah meletakkan nilainilai dasar seperti kesetiaan dan tanggung jawab yang menjadi tujuan kemengadaan manusia dan masyarakat. ${ }^{49}$

Peneropongan sejarah pembentukannya, memperlihatkan bahwa Pela merupakan suatu mekanisme penyelesaian konflik yang ditempuh tidak hanya untuk menyelaraskan kepentingan di antara dua kelompok yang berkonflik, tetapi sekaligus mengikat kedua kelompok itu ke dalam suatu bentuk hubungan yang permanen, yaitu ikatan hidup adik-kakak atau sekandung. Muncul dari situ bentuk aliansi yang baru antara negeri-negeri yang berpela ${ }^{50}$ Pela adalah satu-satunya lembaga tradisional yang mengharuskan adanya kontak teratur antara dua kelompok di tingkat desa, dan dalam Pela inti persaudaraan diuji secara berkala. Ketika sebuah negeri Muslim membantu kelompok Kristen anggota Pela, atau sebaliknya, bantuan ini bukan sekedar bantuan biasa secara ekonomi, tetapi bantuan ini merupakan pernyataan komitmen, tidak hanya kepada sekutu utama seseorang, tetapi juga untuk kepentingan persaudaraan masyarakat secara keseluruhan. ${ }^{51}$

Adat atau tata tertib Pela, yang mengatur hubungan berpela dan bersumber dari mitos (leluhur) adalah pengetahuan yang muncul dari dalam komunitas. Sikap saling percaya, kesetaraan sebagai inti persaudaraan Gandong, satu rahim dalam

\footnotetext{
${ }^{49}$ John Chr. Ruhulessin, Op.Cit, h. 20.

${ }^{50}$ Ibid.

51 Ibid, h. 200.
} 
pencitraan hubungan dan relasi-relasi berpela lahir dari dalam paradigma komunitas itu. Inilah yang mengarahkan sikap dan tingkah laku seseorang dan komunitas untuk mencapai harmoni dan kesatuan secara total, antara masyarakat berpela tetapi juga dengan leluhur mereka. Harmoni dan kesatuan masyarakat berpela dengan leluhur mereka dapat tercipta ketika hubungan-hubungan berpela itu tertata berdasarkan keutamaan-keutamaan, berdasarkan pengetahuan yang lahir dari paradigma masyarakat berpela itu. Harmoni dan kesatuan itu adalah tujuan hakiki dari realitas masyarakat Maluku. ${ }^{52}$

\section{PENUTUP}

\section{Kesimpulan}

Berdasarkan pembahasan, maka dapat diberikan kesimpulan sebagai berikut:

Pertama, Masyarakat salam dan sarane di Maluku memiliki perangkat budaya yang dapat mendorong mereka kepada kehidupan yang rukun, damai, dan sejahtera. Perangkat budaya itu antara lain Pela dan Gandong, kondisi perdamaian yang saat ini berlangsung baik setidaknya menunjukkan berfungsinya elemen-elemen perangkat budaya tersebut. Maka dari itu peranan Pela Gandong sangat berpengaruh dalam mengembalikan kesadaran masyarakat Maluku dalam proses rekonsiliasi konflik demi membawa kedamaian di Maluku.

Kedua, Penyelesaian konflik menurut UndangUndang Nomor 7 Tahun 2012 melingkupi pencegahan konflik, penanganan konflik, dan pemulihan pasca konflik. Pemerintah memberikan porsi bagi pranata adat dalam menyelesaikan konflik yang terjadi, dalam hal ini jika pemerintah tidak dapat menangani konflik yang terjadi maka penyelesaian konflik tersebut dialihkan kepada pranata adat atau lembaga adat yang lahir dari nilai adat yang dihormati, diakui, dan ditaati oleh masyarakat. Maka dari itu pranata adat yang digunakan oleh masyarakat Maluku hingga sekarang ini ialah Pela Gandong, yang mana hasil dari keputusan Pela Gandong ini mengikat antar umat Islam dan umat Kristen.

\section{Rekomendasi}

Konflik-konflik sosial dalam masyarakat baik yang bersifat vertikal maupun horizontal dapat diselesaikan pranata adat yang lahir dari nilai adat

\footnotetext{
${ }^{52}$ Ibid, h. 254.
}

yang dihormati, diakui, dan ditaati oleh masyarakat adat.

\section{DAFTAR PUSTAKA}

\section{Peraturan Perundang-undangan:}

Undang-Undang Dasar 1945.

Undang-Undang Nomor 4 Tahun 1974 tentang Pokok-Pokok Pemerintahan Daerah.

Undang-Undang Nomor 5 Tahun 1979 tentang Sistem

Pemerintahan Desa.

Undang-Undang Nomor 7 Tahun 2012 tentang Penanganan Konflik Sosial.

\section{Buku:}

Cooley, F.L., 1902, Altar and Thome in Central Mollucan Societies, Yale University.

Manuputty, J., 2004, "Konflik Maluku" dalam Lambang Trijono (ed), Potret Retak Nusantara, Studi Kasus terhadap Konflik di Indonesia, Yogyakarta: CSPS Books.

Marasabessy, Suedy (ed), 2002, Maluku Baru, Jakarta.

Marzuki, Peter Mahmud, 2008, Pengantar Ilmu Hukum, Jakarta: Kencana.

Pide, A. Suriyaman Mustari, 2014, Hukum Adat Dahulu, Kini, dan Akan Datang, Jakarta: Kencana.

Pieris, John, 2004, Tragedi Maluku Sebuah Krisis Peradaban, Jakarta: Yayasan Obor.

Piris, John, 2004, Tragedi Maluku: Sebuah Krisis Peradaban, Jakarta: Yayasan Obor Indonesia.

Ruhulessin, John Chr., 2007, Etika Publik Menggali dari Tradisi Pela di Maluku, Salatiga: Satya Wacana University Press.

Stokhof dan Murni Jamal (ed), 2003, Konflik Komunal di Indonesia Saat ini, Jakarta: INIS.

Triyono, Bdk. Lambang, 2001, Keluar dari Kemelut Maluku, Yogyakarta: Pustaka Pelajar.

Waileruny, Semuel, 2010, Membongkar Konspirasi di Balik Konflik Maluku, Jakarta: Yayasan Pustaka Obor.

Wulansari, C. Dewi, 2010, Hukum Adat Indonesia Suatu Pengantar, Bandung: Refika Aditama.

\section{Website:}

Angel, 2010, “Asal Usul Negeri Porto dan Nenek Moyang Talakua", https://willn094.wordpress. com, diakses pada tanggal 25 Nopember 2015. 
Magda, Renny, 2013, “Dasar PerundangUndangan Berlakunya Hukum Adat", http:// rennymagdawiharnani.wordpress.com, diakses pada tanggal 15 Januari 2016.

Sedubun, Nicodemus, 2014, "Pela di Maluku Tengah", http://ohoi-ra.wordpress.com/2014/05/ pela-di-maluku-tengah.com, diakses pada tanggal 01 Desember 2015.
Siwalette, Ricky Yuliam, 2012, “Sejarah Pela Gandong", http://allangforsamua.wordpress. com, (diakses pada tanggal 15 Januari 2016).

Ubbe, Ahmad, 2011, "Laporan Pengkajian Hukum Tentang Mekanisme Penanganan Konflik Sosial", www.bphn.go.id/data/pkj-2011-10.pdf, diakses pada tanggal 29 Mei 2015. 